\title{
Knowledge about tuberculosis in individuals deprived of liberty of a regional penitentiary in the Zona da Mata Mineira - Brazil
}

\author{
Gilberto Caetano Brasil'(D), Rodrigo Siqueira Batistal,II (D), \\ Andréia Patrícia Gomes $^{1}{ }^{(\mathbb{D}}$, Renata Maria Colodette' ${ }^{10}$, \\ Deíse Moura de Oliveira' ${ }^{(i D}$, Tiago Ricardo Moreira'(iD
}

\author{
'Universidade Federal de Viçosa, Viçosa, MG, Brasil \\ "Faculdade Dinâmica do Vale do Piranga, Ponte Nova, MG, Brasil
}

\begin{abstract}
Objective: To evaluate knowledge related to tuberculosis (TB) and to investigate the predictive factors of the prisoners' knowledge status in a regional penitentiary in the Zona da Mata Mineira - Brazil. Methods: This is a cross-sectional and institutionally based study that was conducted with 729 individuals deprived of their liberty in a regional penitentiary. A questionnaire was applied and the detainees 'knowledge about tuberculosis was obtained from the participants' answers to questions about tuberculosis prevention, transmission and treatment. For data analysis, multiple logistic regression was used. Results: Approximately $40 \%$ of the detainees reported not having knowledge about transmission, prevention and treatment of tuberculosis and the lack of knowledge was associated with the following variables: lower education, lower income, closed regime, being the first prison, not having contact with TB outside and inside the prison, not showing symptoms of cough with secretion, weakness and chest pain and not having an HIV test. Conclusion: The lack of knowledge about tuberculosis was associated with education, income, prison terms, first prison, contact with TB outside and inside the prison, symptoms of tuberculosis and HIV testing. The recognition of these factors can contribute to the development of educational interventions aimed at controlling tuberculosis in this population.
\end{abstract}

Keywords: Prison; Knowledge; Tuberculosis 


\section{INTRODUCTION}

Tuberculosis (TB) is a serious infectious disease, transmissible and curable, transmitted by air, from inhalation containing bacilli, by coughing, speaking or sneezing by the carrier of the active disease (pulmonary or laryngeal), and may reach other organs or occur from disseminated form (FURIN, COX, PAI, 2019).

The most vulnerable populations to be infected with TB are indigenous people, people living with HIV / AIDS (Human Immunodeficiency Virus / Acquired Immunodeficiency Syndrome), homeless individuals, health professionals and populations deprived of their freedom (BRASIL, 2019).

The occurrence of active tuberculosis in prisons is generally reported to be much greater than that of the corresponding general population (MOREIRA et al., 2019; BAUSSANO et al., 2010). Even so, prisons are often ignored by national health sectors and are not included in national statistics (DARA et al., 2015).

The highest incidence of tuberculosis in prisons is not limited to prisoners only, but also to employees, family members and the entire community that relates to them during and after prison (SACRAMENTO, GONÇALVEZ ,2017). Prison units, regardless of their capacity, "represent a reservoir disease transmission to the community in general. As such, effective tuberculosis control in this environment can prevent the infection from spreading to the general population through staff, visitors and close contacts with released prisoners" (NIVEAU, 2006).

The conflictive, difficult and insecure relationship between prisoners and professionals responsible for security, management and all the support staff, especially the health team, hinder everyone's work, resulting in a greater loss of quality of life and well-being of them, being an obstacle to the prevention, treatment and cure of diseases that occur in this population. In the case of TB, in particular, there is a delay in diagnosis, treatment, and bacilliferous cases are rarely diagnosed and, when diagnosed, are most often at a later stage of the disease (BRASIL, 2015). 
Still regarding existing obstacles to TB control in these places, psychological and social peculiarities (overcrowding, clinical complications and drug resistance, exposure to the bacillus, complex and costly conditions) are observed in relation to the organization and functioning of these prison institutions, mainly in the preventive field (SOUZA et al., 2012). The underestimation of the symptoms of the disease, the inadequacy and inefficiency of TB Control Programs for the prison population and the barriers that prevent access lead the population to have worse indicators, higher rate of treatment abandonment, low cure and multidrug resistance (MOREIRA, FAVERO, MACIEL, 2010; SOUZA et al., 2012).

Systematic screening of contacts and high-risk groups is one of the pillars of the Global End TB strategy (WHO, 2019), but many penitentiary systems face a variety of challenges that prevent TB control. These include, among others, insufficient laboratory capacity and diagnostic tools, interruptions in the supply of medicines, poor integration between tuberculosis services in the health and prison systems, inadequate infection control measures and low political priority for prison care (DARA et al., 2015).

Another barrier to TB control in prisons refers to the lack of knowledge about the disease in these environments. Research conducted with managers, health professionals, security agents and inmates with TB in prisons in three countries (Bolivia, Ecuador and Paraguay) found that stigmatizing attitudes and low knowledge about TB among detainees and prison officers discouraged people living in prisons seeking diagnosis and treatment (WAISBORD, 2010).

A study carried out in Ethiopian prisons showed that only $1.6 \%$ of detainees described the cause of TB as being bacterial, while a "wind" known locally as 'nefas' was frequently mentioned. About $75 \%$ of prisoners correctly described breathing as a mode of TB transmission, $30.7 \%$ did not know any measures for TB prevention and control, and half of the participants did not know that anti-tuberculosis drugs were provided free of charge (ABEBE et al., 2011). 
The lack of knowledge about the disease was also reported by two-thirds of the family members of people with $\mathrm{TB}$, which may be one more reason why the goals of curing the disease in criminal establishments are not achieved. The authors reinforce the need to extend health education activities to family members of TB patients, as this way, they would become more support in controlling the disease in and out of the prison environment (COSTA et al., 2011).

TB control could be significantly improved if more consideration was given to the population's knowledge about TB and the behavior related to seeking health care, directing efforts to make individuals more informed and aware of all aspects of TB, its treatment and basic rules to prevent the spread of the disease to their contacts (members of the community and family, prison staff, inmates and others who have social or physical contact with TB patients) (ABEBE et al., 2011; STORLA, YIMER, BJUNE, 2008).

In Brazil, studies on the knowledge of TB (transmission, prevention and treatment) by detainees are still scarce. Thus, the objectives of the present study were, therefore, to assess the level of knowledge related to TB and to investigate the predictive factors of the prisoners' knowledge status in a regional penitentiary in the Zona da Mata Mineira - Brazil.

\section{MATERIAL AND METHODS}

This is an observational, individual cross-sectional and institutionally based study that was conducted with individuals deprived of liberty in a regional penitentiary in the Zona da Mata Mineira. The study was approved by the Research Ethics Committee of the Federal University of Viçosa (Opinion 2,701,921).

This prison unit consists of 4 pavilions, pavilions 1 and 2 consisting of 56 cells each, where they house an average of 4 prisoners per cell. Pavilion 3 has 23 cells that house 12 to 14 prisoners and Pavilion 4 with 9 cells that house 4 to 9 prisoners. The prison's nominal capacity is 396 inmates, but in July 2018, it held 798 inmates. 
The penitentiary houses inmates from closed and semi-open regimes. As it is a regional penitentiary, the turnover of prisoners is relatively high internally and externally, in addition to the progression of the regime.

The base population for the study was composed of male prisoners who were incarcerated in the penitentiary at the time of data collection. All closed and semiopen detainees were included. Inmates were excluded when contact and access was not possible and / or allowed, for security reasons, for health reasons (hospitalization) and others (decision of the prison administration), and those who refused to participate in the research. In all, 729 (91.4\%) inmates met the inclusion and exclusion criteria and participated in the survey.

Data collection was carried out between July and September 2018. During this period, prisoners were sequentially extracted from their cells by groups and taken to the penitentiary's health service, at a rate stipulated by the penitentiary's coordination. Three interviewers performed data collection. They were trained in the whole process of data collection and about the objectives of the study.

Initially, a confidential and individual approach was taken to request the signing of the Free and Informed Consent Form. Subsequently, for those who agreed to participate in the study, a structured and pre-tested questionnaire was applied, containing questions about sociodemographic, clinical, lifestyle, prison conditions and knowledge about tuberculosis. The questionnaire was based on studies by Costa et al (2011), Freitas et al. (2012), and Ferreira Júnior et al (2013).

The detainees 'knowledge about tuberculosis was assessed based on the participants' responses to the questions: How do you get Tuberculosis? (Streaming); How to prevent tuberculosis? (Prevention); and How is Tuberculosis cured? (Treatment). The answers were categorized as "right" and "wrong".

As independent variables, socioeconomic variables were considered (age, years of schooling, color, existence of a partner, work situation before prison, income before prison), prison situation (prison regime, length of imprisonment, first prison), lifestyle habits (use of alcohol, tobacco and illicit drugs), contact with 
tuberculosis patients (outside the prison, inside the prison), HIV testing, presence of BCG scarring and tuberculosis symptoms (cough, lung secretion), shortness of breath, chest pain, fever, weakness, night sweat and weight loss).

Descriptive analysis of the data was conducted with the description of the population through the distribution of absolute and relative frequencies, mean and standard deviation. The prevalence of errors in questions of knowledge about tuberculosis was estimated and their association with the characteristics of detainees was investigated using bivariate and multivariate logistic regression. The strength of the association between knowledge of tuberculosis and the explanatory variables was assessed using the odds ratio (OR) and their respective 95\% confidence intervals.

Considering the objectives of this research, the backward elimination method by Wald test was used to select the final model of multivariate logistic regression. This method begins with the inclusion of all significant explanatory variables in the bivariate analysis $(p<0.20)$. The variables are then removed one at a time, starting with the one with the highest $p$-value in the Wald test. The equation is evaluated at each stage and the procedure is repeated until each variable that remains in the model explains a significant portion of the variation observed in the response (PAGANO, 2010). In the multivariate model, the variables that presented $p<0.05$ will be considered significant. All analyzes were performed using the Epi info 7.0 program.

\section{RESULTS}

Of the 729 inmates participating in the study, more than half reported being black/brown, had no partner, worked before being arrested, had a monthly income of up to 01 minimum wages. The average age was 32.8 years $(S D=9.8)$ and years of study was 7.0 (SD = 2.8). About $70 \%$ of detainees were in the closed prison system and $51 \%$ reported incarceration times of up to 40 months. Other characteristics of interest are shown in table 1. 
Table 1 - Characteristics, socioeconomic, clinical and lifestyle habits of the population deprived of liberty, 2018

\begin{tabular}{|c|c|c|}
\hline Variables & $\mathbf{N}$ & $\%$ \\
\hline \multicolumn{3}{|l|}{ Color } \\
\hline White & 198 & $27,2 \%$ \\
\hline Black & 159 & $21,8 \%$ \\
\hline Brown & 336 & $46,0 \%$ \\
\hline Yellow & 21 & $2,9 \%$ \\
\hline Indígenous & 15 & $2,1 \%$ \\
\hline \multicolumn{3}{|l|}{ Has a companion } \\
\hline Yes & 270 & $37,0 \%$ \\
\hline No & 459 & $63,0 \%$ \\
\hline \multicolumn{3}{|c|}{ Worked before being arrested } \\
\hline Yes & 572 & $78,5 \%$ \\
\hline No & 157 & $21,5 \%$ \\
\hline \multicolumn{3}{|c|}{ Monthly income before being arrested } \\
\hline$<=100,00$ & 182 & $25,1 \%$ \\
\hline $101,00-954,00$ & 206 & $28,4 \%$ \\
\hline $955,00-1500,00$ & 184 & $25,3 \%$ \\
\hline $1501,00+$ & 154 & $21,2 \%$ \\
\hline \multicolumn{3}{|l|}{ Regime } \\
\hline Fechado & 507 & $69,5 \%$ \\
\hline Semiaberto & 222 & $30,5 \%$ \\
\hline \multicolumn{3}{|l|}{ It's your first prison } \\
\hline Yes & 229 & $31,4 \%$ \\
\hline No & 500 & $68,6 \%$ \\
\hline \multicolumn{3}{|c|}{ Incarceration time in months } \\
\hline$<=21,00$ & 186 & $25,5 \%$ \\
\hline $21,01-40,00$ & 186 & $25,5 \%$ \\
\hline $40,01-72,00$ & 186 & $25,5 \%$ \\
\hline $72,01+$ & 170 & $23,5 \%$ \\
\hline \multicolumn{3}{|l|}{ Smoking } \\
\hline Ex-smoker & 165 & $22,6 \%$ \\
\hline Smoker & 400 & $54,9 \%$ \\
\hline Never smoked & 164 & $22,5 \%$ \\
\hline \multicolumn{3}{|l|}{ Use of alcoholic beverages } \\
\hline Yes, sometimes & 408 & $56,0 \%$ \\
\hline Yes, often & 206 & $28,2 \%$ \\
\hline No & 115 & $15,8 \%$ \\
\hline
\end{tabular}


Continuation...

\begin{tabular}{lcc}
\hline \multicolumn{1}{c}{ Variables } & N & \% \\
\hline Use of drugs & & \\
Yes, inhalable & 540 & $74,0 \%$ \\
Yes, injectables & 23 & $3,2 \%$ \\
Yes, inhalable and injectables & 24 & $3,3 \%$ \\
No & 142 & $19,5 \%$ \\
Had tuberculosis & & \\
Yes & 29 & $4,0 \%$ \\
No & 682 & $93,5 \%$ \\
Do not know & 18 & $2,5 \%$
\end{tabular}

Contact OUTSIDE of the prison with someone with TB

Yes

81

$11,1 \%$

No

616

$84,5 \%$

Do not konw

32

$4,4 \%$

Contact INSIDE the prison with someone with TB

Yes

No

Do not know

HIV tested

Yes

No

You have a cough

Yes, more than two weeks

Yes, less than two weeks

No

\section{Has secretion when coughing}

Yes

No

Shortness of breathe

Yes

No

\section{Sore chest pain}

Yes

No

Fever in the last 2 weeks

\begin{tabular}{lcc} 
Yes & 65 & $8,9 \%$ \\
No & 664 & $91,1 \%$ \\
\hline & & Continuation... \\
\hline
\end{tabular}




\begin{tabular}{lcc}
\hline \multicolumn{1}{c}{ Conclusion } & & \\
\hline \multicolumn{1}{c}{ Vense of weakness } & N & $\%$ \\
Yes & 110 & $15,1 \%$ \\
No & 617 & $84,9 \%$ \\
Night Sweating & & \\
Yes & 119 & $16,4 \%$ \\
No & 606 & $83,6 \%$ \\
Lost weight in the last 3 months & & \\
Yes & 133 & $18,3 \%$ \\
No & 593 & $81,7 \%$ \\
\hline
\end{tabular}

Source: Author

Among the study participants, approximately $60 \%$ answered the question about transmission of tuberculosis, $53.2 \%$ answered the question about prevention and $64.3 \%$ answered the question about treatment. About $4 \%$ are unaware of who can get TB (Table 2). In the bivariate analysis, the chance of missing the questions about transmission, prevention and treatment of tuberculosis was greater in individuals with less education, lower income, with closed prison terms, who were in the first prison, with less time in prison, who did not report contact with TB inside the prison, did not undergo an HIV test and reported tuberculosis symptoms (cough with discharge, fever, weakness and weight loss) (Table 3).

Table 2 - Knowledge about tuberculosis in the population deprived of liberty, 2018

\begin{tabular}{lcc}
\hline & N & \% \\
\hline How to get Tuberculosis (Transmission) & & \\
Right & 436 & $59,8 \%$ \\
Wrong & 293 & $40,2 \%$ \\
How to Prevent Tuberculosis (Prevention) & 388 & $53,2 \%$ \\
Right & 341 & $46,8 \%$ \\
Wrong & & \\
Who can get Tuberculosisuem & 697 & $95,6 \%$ \\
Right & 32 & $4,4 \%$ \\
Wrong & & \\
How to cure Tuberculosis (Treatment) & 469 & $64,3 \%$ \\
Right & 260 & $35,7 \%$ \\
Wrong & & \\
\hline
\end{tabular}

Souce: Author 
Table 3 - Association between knowledge about transmission, prevention and treatment of tuberculosis and socioeconomic, clinical, prison conditions and life habits of the population deprived of liberty, 2018

\begin{tabular}{|c|c|c|c|c|c|c|}
\hline & \multirow{2}{*}{$\begin{array}{c}\text { TB } \\
\text { Transmission } \\
\text { OR (IC95\%) }\end{array}$} & \multicolumn{2}{|r|}{$\begin{array}{c}\text { TB } \\
\text { Prevetion } \\
\end{array}$} & \multicolumn{3}{|c|}{$\begin{array}{c}\text { TB } \\
\text { Treatment }\end{array}$} \\
\hline & & $p^{*}$ & OR (IC95\%) & $p^{*}$ & OR (IC95\%) & $p^{*}$ \\
\hline Age in years & $1,00(0,99-1,02)$ & 0,796 & $1,00(0,98-1,01)$ & 0,910 & $0,99(0,97-1,00)$ & 0,080 \\
\hline Years of study & $0,90(0,85-0,95)$ & $<0,001$ & $0,97(0,92-1,02)$ & 0,198 & $0,92(0,87-0,97)$ & 0,002 \\
\hline Color & & 0,477 & & 0,208 & & 0,751 \\
\hline White & 1 & & 1 & & 1 & \\
\hline Black & $1,22(0,80-1,86)$ & & $1,32(0,87-2,01)$ & & $0,94(0,61-1,45)$ & \\
\hline Brown & $0,89(0,61-1,27)$ & & $0,94(0,66-1,34)$ & & $0,83(0,58-1,20)$ & \\
\hline Yellow & $1,34(0,54-3,31)$ & & $0,86(0,34-2,14)$ & & $0,82(0,32-2,12)$ & \\
\hline Indigenous & $0,74(0,24-2,24)$ & & $0,42(1,3-1,36)$ & & $1,44(0,50-4,12)$ & \\
\hline \multicolumn{2}{|c|}{ Has a companion } & 0,240 & & 0,153 & & 0,910 \\
\hline Yes & 1 & & 1 & & 1 & \\
\hline No & $1,20(0,88-1,64)$ & & $1,25(0,92-1,69)$ & & $0,98(0,72-1,34)$ & \\
\hline \multicolumn{2}{|c|}{ Worked before being arrested } & 0,840 & & 0,919 & & 0,999 \\
\hline Yes & 1 & & 1 & & 1 & \\
\hline No & $0,96(0,67-1,38)$ & & $1,02(0,72-1,45)$ & & $1,00(0,69-1,45)$ & \\
\hline \multicolumn{2}{|c|}{$\begin{array}{l}\text { Monthly income before being } \\
\text { arrested }\end{array}$} & 0,082 & & $<0,001$ & & 0,002 \\
\hline$<=100,00$ & 1 & & 1 & & 1 & \\
\hline $101,00-954,00$ & $1,17(0,79-1,76)$ & & $1,40(0,94-2.09)$ & & $1,28(0,85-1,93)$ & \\
\hline \multicolumn{7}{|l|}{1500,00} \\
\hline $1501,00+$ & $1,02(0,66-1,57)$ & & $0,59(0,38-0,92)$ & & $0,52(0,32-0,85)$ & \\
\hline Regime & & 0,001 & & 0,852 & & 0,299 \\
\hline Closed & 1 & & 1 & & 1 & \\
\hline Semi-open & $0,57(0,41-0,80)$ & & $1,03(0,75-1,41)$ & & $0,84(0,60-1,17)$ & \\
\hline \multicolumn{2}{|c|}{ It's your first prison } & $<0,001$ & & 0,011 & & 0,957 \\
\hline Yes & 1 & & 1 & & 1 & \\
\hline No & $0,56(0,41-0,77)$ & & $0,67(0,49-0,91)$ & & $0,99(0,72-1,37)$ & \\
\hline \multicolumn{2}{|c|}{ Incarceration time in months } & 0,049 & & 0,673 & & 0,316 \\
\hline$<=21,00$ & 1 & & 1 & & 1 & \\
\hline $21,01-40,00$ & $0,77(0,51-1,16)$ & & $0,84(0,64-1,44)$ & & $0,39(0,54-1,27)$ & \\
\hline $40,01-72,00$ & $0,70(0,47-1,06)$ & & $0,79(0,52-1,19)$ & & $1,00(0,66-1,52)$ & \\
\hline $72,01+$ & $0,55(0,36-0,81)$ & & $0,95(0,63-1,44)$ & & $0,70(0,45-1,08)$ & \\
\hline Smoking & & 0,774 & & 0,121 & & 0,978 \\
\hline Ex smoker & 1 & & 1 & & 1 & \\
\hline Smoker & $0,98(0,68-1,42)$ & & $1,23(0,85-1,77)$ & & $1,04(0,71-1,52)$ & \\
\hline Never smoked & $0,87(0,56-1,35)$ & & $0,85(0,55-1,32)$ & & $1,01(0,64-1,59)$ & \\
\hline \multicolumn{2}{|c|}{ Use of alcoholic beverages } & 0,524 & & 0,655 & & 0,180 \\
\hline Yes, sometime & 1 & & 1 & & 1 & \\
\hline Yes, often & $0,91(0,64-1,28)$ & & $0,94(0,68-1,32)$ & & $1,15(0,81-1,63)$ & \\
\hline No & $1,19(0,78-1,80)$ & & $1,18(0,77-1,77)$ & & $1,49(0,97-2,27)$ & \\
\hline Use of drugs & & 0,505 & & 0,632 & & 0,569 \\
\hline Yes, inhalable & 1 & & 1 & & 1 & \\
\hline
\end{tabular}




\begin{tabular}{|c|c|c|c|c|c|c|}
\hline \multicolumn{7}{|l|}{ Conclusion } \\
\hline & \multicolumn{2}{|l|}{$\begin{array}{c}\text { TB } \\
\text { Transmission }\end{array}$} & \multicolumn{2}{|l|}{$\begin{array}{c}\text { TB } \\
\text { Prevetion }\end{array}$} & \multicolumn{2}{|l|}{$\begin{array}{c}\text { TB } \\
\text { Treatment }\end{array}$} \\
\hline & OR (IC95\%) & $p^{*}$ & OR (IC95\%) & p* & OR (IC95\%) & p* \\
\hline Use of drugs & & 0,505 & & 0,632 & & 0,569 \\
\hline Yes, Injectables & $1,42(0,62-3,30)$ & & $0,58(0,24-1,40)$ & & $0,04(0,25-1,64)$ & \\
\hline $\begin{array}{l}\text { Sim, inhalable e } \\
\text { injectables }\end{array}$ & $0,78(0,39-1,85)$ & & $0,93(0,41-2,10)$ & & $1,52(0,67-3,46)$ & \\
\hline No & $1,24(0,86-1,81)$ & & $0,90(0,62-1,30)$ & & $0,98(0,66-1,44)$ & \\
\hline \multicolumn{2}{|c|}{ TB contact outside prison } & 0,084 & & 0,056 & & 0,087 \\
\hline Yes & 1 & & 1 & & 1 & \\
\hline No & $1,71(1,04-2,83)$ & & $1,27(0,79-2,03)$ & & $1,81(1,06-3,07)$ & \\
\hline Do not know & $1,24(0,52-2,97)$ & & $2,78(1,18-6,52)$ & & $1,60(0,66-3,88)$ & \\
\hline \multicolumn{2}{|c|}{ Contact with TB inside the prison } & 0,037 & & 0,704 & & 0,015 \\
\hline Yes & 1 & & 1 & & 1 & \\
\hline No & $1,56(1,11-2,21)$ & & $1,15(0,83-1,60)$ & & $1,38(0,97-1,96)$ & \\
\hline Do not know & $1,27(0,60-2,69)$ & & $1,12(0,54-2,32)$ & & $0,47(0,19-1,19)$ & \\
\hline HIV Tested & & 0,070 & & 0,024 & & 0,006 \\
\hline Yes & 1 & & 1 & & 1 & \\
\hline No & $1,40(0,72-2,03)$ & & $1,53(1,06-2,21)$ & & $1,67(1,15-2,42)$ & \\
\hline Had Cough & & 0,300 & & 0,181 & & 0,970 \\
\hline $\begin{array}{l}\text { Yes, } \geq \text { two } \\
\text { weeks }\end{array}$ & 1 & & 1 & & 1 & \\
\hline $\begin{array}{l}\text { Yes, }<\text { two } \\
\text { weeks }\end{array}$ & $0,90(0,53-1,54)$ & & $1,00(0,59-1,70)$ & & $0,95(0,54-1,64)$ & \\
\hline No & $0,760,52-1,10)$ & & $0,75(0,52-1,08)$ & & $1,01(0,69-1,47)$ & \\
\hline \multicolumn{2}{|c|}{ Has secretion when coughing } & 0,003 & & 0,073 & & 0,204 \\
\hline Yes & 1 & & 1 & & 1 & \\
\hline No & $0,61(0,44-0,85)$ & & $0,75(0,54-1,03)$ & & $1,24(0,89-1,75)$ & \\
\hline \multicolumn{2}{|c|}{ Shortness of breath } & 0,062 & & 0,001 & & 0,912 \\
\hline Yes & 1 & & 1 & & 1 & \\
\hline No & $0,71(0,49-1,02)$ & & $0,53(0,37-0,77)$ & & $0,98(0,67-1,43)$ & \\
\hline \multicolumn{2}{|l|}{ Sore chest pain } & 0,448 & & $\begin{array}{c}<0,00 \\
1\end{array}$ & & 0,694 \\
\hline Yes & 1 & & 1 & & 1 & \\
\hline No & $0,87(0,61-1,25)$ & & $0,52(0,36-0,74)$ & & $0,93(0,64-1,34)$ & \\
\hline \multicolumn{2}{|c|}{$\begin{array}{l}\text { Has had a fever in the past } 2 \\
\text { weeks }\end{array}$} & 0,004 & & 0,025 & & 0,961 \\
\hline Yes & 1 & & 1 & & 1 & \\
\hline No & $0,48(0,28-0,80)$ & & $0,56(0,33-0,94)$ & & $1,01(0,60-1,73)$ & \\
\hline \multicolumn{2}{|c|}{ Sense of weakness } & 0,014 & & 0,117 & & 0,636 \\
\hline Yes & 1 & & 1 & & 1 & \\
\hline No & $0,60(0,40-0,90)$ & & $0,72(0,48-1,09)$ & & $1,11(0,72-1,70)$ & \\
\hline Night sweating & & 0,226 & & 0,297 & & 0,726 \\
\hline Yes & 1 & & 1 & & 1 & \\
\hline No & $1,29(0,86-1,94)$ & & $0,81(0,55-1,20)$ & & $1,08(0,71-1,63)$ & \\
\hline \multicolumn{2}{|c|}{ Lost weight in the last 3 months } & 0,014 & & 0,832 & & 0,393 \\
\hline Yes & $0,63(0,43-0,91)$ & & 1 & & 1 & \\
\hline No & & & $1,04(0,71-1,52)$ & & $1,19(0,80-1,78)$ & \\
\hline
\end{tabular}

* Significance of the Wald Test; TB: Tuberculosis. Source: Author 
In the multivariate analysis, the following variables remain independently associated with a greater chance of not knowing about tuberculosis prevention, transmission or treatment: being in a closed prison system, not knowing or not having contact with tuberculosis outside or inside the prison, and not having an HIV test. Higher education, income equal to or greater than $\mathrm{R} \$ 1,501.00$ reais, not being in the first prison, and not reporting symptoms of tuberculosis (cough with secretion, weakness and chest pain) were associated with a lower chance of not knowing about tuberculosis (Table 4).

Table 4 - Final multivariate model of socioeconomic, clinical and lifestyle habits associated with knowledge about tuberculosis in the population deprived of liberty, 2018

\begin{tabular}{|c|c|c|c|c|c|c|}
\hline & \multicolumn{2}{|c|}{ Transmission } & \multicolumn{2}{|c|}{ Prevention } & \multicolumn{2}{|c|}{ Treatment } \\
\hline & OR (IC95\%) & $p^{*}$ & OR (IC95\%) & p* & OR (IC95\%) & p* \\
\hline Years of study & $0,92(0,87-0,97)$ & 0,002 & & & & \\
\hline Income & & & & 0,001 & & $<0,001$ \\
\hline$<100,00$ & & & 1 & & 1 & \\
\hline $101,00-954,00$ & & & $\begin{array}{c}1,29(0,86- \\
1,95)\end{array}$ & 0,216 & $1,33(0,89-2,00)$ & 0,167 \\
\hline $\begin{array}{l}955,00- \\
1500,00\end{array}$ & & & $\begin{array}{c}1,32(0,86- \\
2,01)\end{array}$ & 0,200 & $1,34(0,88-2,03)$ & 0,174 \\
\hline $\begin{array}{l}1501,00 \text { or } \\
\text { more }\end{array}$ & & & $\begin{array}{c}0,56(0,36- \\
0,89)\end{array}$ & 0,014 & $0,56(0,36-0,89)$ & 0,014 \\
\hline Prison regime & & 0,003 & & & & \\
\hline Semi-open & 1 & & & & & \\
\hline Closed & $1,72(1,20-2,44)$ & & & & & \\
\hline First prison & & 0,002 & & 0,025 & & \\
\hline Yes & 1 & & 1 & & & \\
\hline No & $0,60(0,43-0,83)$ & & $\begin{array}{c}0,69(0,49- \\
0,95)\end{array}$ & & & \\
\hline $\begin{array}{l}\text { TB contact } \\
\text { outside prison }\end{array}$ & & 0,028 & & 0,040 & & 0,036 \\
\hline Yes & 1 & & 1 & & 1 & \\
\hline No & $2,24(1,22-4,11)$ & 0,009 & $\begin{array}{c}1,42(0,86- \\
2,33)\end{array}$ & 0,167 & $1,45(0,88-2,38)$ & 0,143 \\
\hline Do not know & $1,64(0,61-4,45)$ & 0,330 & $\begin{array}{c}3,12(1,29- \\
7,50)\end{array}$ & 0,011 & $3,15(1,32-7,55)$ & 0,010 \\
\hline Contact with & & & & & & \\
\hline $\begin{array}{l}\text { TB inside the } \\
\text { prison }\end{array}$ & & 0,068 & & & & \\
\hline Yes & 1 & & & & & \\
\hline No & $1,55(1,07-2,24)$ & 0,020 & & & & \\
\hline Do not know & $1,35(0,60-3,02)$ & 0,469 & & & & \\
\hline
\end{tabular}




\begin{tabular}{|c|c|c|c|c|c|c|}
\hline \multicolumn{7}{|l|}{ Conclusion } \\
\hline & \multicolumn{2}{|c|}{ Transmission } & \multicolumn{2}{|c|}{ Prevention } & \multicolumn{2}{|c|}{ Treatment } \\
\hline & OR (IC95\%) & p* & OR (IC95\%) & p* & OR (IC95\%) & $p^{*}$ \\
\hline Has secretion & & & & & & \\
\hline $\begin{array}{l}\text { when } \\
\text { coughing }\end{array}$ & & 0,033 & & & & \\
\hline Yes & 1 & & & & & \\
\hline No & $0,68(0,48-0,97)$ & & & & & \\
\hline Feeling Weak & & 0,016 & & & & \\
\hline Yes & 1 & & & & & \\
\hline No & $0,57(0,37-0,90)$ & & & & & \\
\hline Chest pain & & & & $<0,001$ & & $<0,001$ \\
\hline Yes & & & 1 & & 1 & \\
\hline No & & & $0,47(0,32-0,68)$ & & $0,48(0,33-0,70)$ & \\
\hline HIV Tested & & & & 0,034 & & 0,019 \\
\hline Yes & & & 1 & & 1 & \\
\hline No & & & $1,51(1,03-2,22)$ & & $1,57(1,08-2,30)$ & \\
\hline
\end{tabular}

* Significance of the Wald Test; OR: Odds Ratio: 95\% Cl: 95\% Confidence Interval; TB: Tuberculosis. Source; Author

\section{DISCUSSION}

The results of the present study show that about $40 \%$ of the detainees reported ignorance about tuberculosis prevention, transmission and treatment. Individuals with higher education, higher income, who were not in the first prison, and who do not have symptoms of TB were less likely to miss the questions about prevention of TB transmission and treatment. It was associated with a greater chance of not knowing about TB, being in a closed prison system, not having contact outside and inside the prison unit with infected people and not having been tested for HIV/AIDS.

The present study identified that most detainees are aware of TB, with $60 \%$ of how it is transmitted, $53 \%$ of how it is prevented and $64 \%$ of treatment. This result contrasts with the findings by Santana et al. (SANTANA et al., 2015), where among the inmates interviewed, $98 \%$ of them said they had already received some information about TB (SANTANA et al., 2015). And another study showed that the families of prisoners, as well as health professionals who work in prisons, need to have more knowledge, especially about transmission (RÊEGO et al., 2017). 
Studies carried out in other populations also demonstrate gaps in knowledge about TB. Among doctors and nurses, primary health care identified gaps in knowledge and attitude regarding how to treat contacts of patients with tuberculosis (RAMOS et al., 2018) Among community health workers, although they are professionals on the frontline of primary care, they reported ignorance about occupational risk that brings it to health professionals (ROCHA et al., 2015; SIQUEIRA-BATISTA et al., 2011). Families with individuals with TB have difficulty dealing with the disease due to lack of knowledge regarding transmission, protection and care for patients (FREITAS et al., 2015).

The detainees' lack of knowledge about TB is worrying, not only in the prison environment, but mainly when they are released due to the danger of transmission between their family, friends and the whole community with whom they relate (VITTI JUNIOR, 2013). The lack of knowledge about the disease is one of the main barriers to the perception of symptoms. A study carried out in a prison unit in the interior of the state of São Paulo, Brazil highlights misconceptions about the disease by prison staff and that the level of education was insufficient for clinical practice in combating, preventing and treating the disease (FERREIRA JÚNIOR et al, 2013). Studies suggest the need for continuing education not only in the prison population, but also in prison units (FERREIRA JÚNIOR et al, 2013; VITTI JUNIOR, 2013).

In the present study, individuals with higher education and income were less likely to err on the questions about prevention of TB transmission and treatment. Individuals with low education, low income and restricted access to information, have a greater chance of not knowing about TB (VITTI JÚNIOR, 2013). Similar results found by Adane et al. (2017), when they showed that the prisoners' knowledge regarding the cause of TB and the consequences of non-adherence to TB treatment were low. However, knowledge about transmission, symptoms and prevention was relatively high. Health education interventions, focused on the cause and 
knowledge focused on appropriate practices, are necessary in all prison units and special attention should be given to prisoners with less education.

As for the type of prison regime, inmates in the closed regime were 1.7 times more likely to miss the issue of TB transmission. This result may be associated with access to more information about the disease that semi-open prisoners may have outside prison (campaigns on TV, internet, radio, access to health services, among others). Detainees serving half-open sentences for relating to the community may receive more information about the disease (FERREIRA JÚNIOR et al., 2013).

In the same way, prisoners who have been to more than one prison and who had contact with or proximity to individuals with TB showed less ignorance about TB. Previous experience with the prison environment and with tuberculosis may have led to learning about the disease. This fact has already been demonstrated among family members of people with TB where knowledge was associated with the condition of having this disease and the fact that a case of YB in the family has already occurred. These results indicate the need to intensify educational actions, which need to be directed to detainees, nurses, family members and the community in general (COSTA et al., 2011).

Prisoners who tested for HIV could be more concerned with their health and, therefore, sought more knowledge about other health problems that exist in prisons, including TB. Studies indicate that people living with HIV are 28 times more likely to contract TB (WHO, 2019). For every patient with suspected HIV, the TB test should also be provided, as well as the opposite, that is, every patient with suspected TB should also be provided. offered an HIV test. The close relationship between the two diseases can provide knowledge about TB (BRASIL, 2019).

As for the presentation of TB symptoms, asymptomatic patients are less likely to know about TB (transmission, prevention and treatment). People who showed symptoms of TB made the most mistakes, which can compromise the early diagnosis and timely treatment of TB in the prison environment. Ferreira Junior et 
al (2013) says that there are several barriers to detect the symptoms of TB in populations at risk such as prisoners, but the main one is the lack of knowledge about the disease, perception of symptoms, early diagnosis, adherence to the treatment and cure. On the other hand, Sánchez et al. (SÁNCHEZ et al., 2007) believes that the undervaluation of TB symptoms in a violent and precarious environment, such as prison units, where other concerns are prioritized such as survival in this extremely hostile scenario.

The present study has some limitations. One to be mentioned refers to loss. About $8.6 \%$ (69) of the detainees did not answer the questionnaire. This fact is justified by the turnover of detainees in the penitentiary, by the semi-open prison regime (the detainees were out of prison at the time of data collection) and because some detainees achieved conditional or permanent freedom during the data collection period.

\section{CONCLUSION}

Approximately $40 \%$ of detainees reported not having knowledge about TB Transmission, Prevention and Treatment. And this lack of knowledge was associated with lower schooling, lower income, closed prison system, being stuck in the first prison, not having contact with TB outside and inside the prison, showing symptoms of TB and not having an HIV test.

It is a considerable percentage of ignorance. It reinforces and highlights the need to establish health education practices in prisons in a more systematic way. The recognition of these factors can contribute to the development of these interventions and direct better control of tuberculosis in the prison population.

\section{REFERENCES}

ABEBE, D.S., et al. Assessment of knowledge and practice about tuberculosis among eastern Ethiopian prisoners. Int J Tuberc Lung Dis. v.15, n. 2, p. 228-233, Fev, 2011. 
ADANE, K., et al. Tuberculosis knowledge, attitudes, and practices among northern Ethiopian prisoners: Implications for TB control efforts. Plos One. v.12, n. 3, E0174692, Mar, 2017.

AKEKE, V.; MOKGATLE, M., OGUNTIBEJU, O. Knowledge, Attitudes and Practices that facilitate the transmission of HIV among prison inmates: a review. KMJ. v.39, n.4, p. 310318, Dec, 2007.

BAUSSANO, I., et al. Tuberculosis incidence in prisons: a systematic review. Plos Med. v.7, n. 12, E1000381, Dec. 2010.

BRASIL. Manual de Recomendações para o Controle da Tuberculose no Brasil. Ministério da Saúde/Secretaria de Vigilância em Saúde/Departamento de Vigilância das Doenças Transmissíveis. 2 ed. Brasília: Ministério da Saúde, 2019.

BRASIL. Ministério da Saúde. Secretaria de Vigilância em saúde. Tuberculose. Situação epidemiológica estados associados ao Mercosul. Brasília, DF, 2015 p.19.

COSTA, S. M. et al. Conhecimento dos clientes com tuberculose pulmonar e seus familiares sobre adesão ao tratamento e fatores associados, no município do Rio Grande (RS). Ciênc. saúde coletiva, Rio de Janeiro, v. 16, supl. 1, p. 1427-1435, 2011.

DARA, M., et al. Tuberculosis control in prisons: current situation and research gaps. Int J Infect Dis. v. 32, p.111-7, Mar, 2015.

FERREIRA JUNIOR, S; OLIVEIRA, H.B.; MARIN-LEON, L. Knowledge, attitudes and practices on tuberculosis in prisons and public health services. Rev. bras. Epidemiol. São Paulo, v. 16, n. 1, p. 100-113, Mar. 2013.

FREITAS, I.M., et al. Knowledge and perception about tuberculosis of patients' families under directly observed treatment at a health service in Ribeirão Preto-SP, Brazil. Texto contexto - enferm. Florianópolis, v. 21, n. 3, p. 642-649, Sep. 2012.

FREITAS, I.M.,et al. Factors associated with knowledge about tuberculosis and attitudes of relatives of patients with the disease in Ribeirão Preto, São Paulo, Brazil. Rev. bras. Epidemiol. São Paulo, v. 18, n. 2, p. 326-340, Jun, 2015.

FURIN, J.; COX, H.; PAI, M. Tuberculosis. Lancet, v. 393, n. 10181, p. 1642-1656, 2019.

MOREIRA, T.R.; FÁVERO, J.L.; MACIEL, E.L.N. Tuberculose no sistema prisional capixaba. Revista Brasileira de Pesquisa em Saúde. Vitória, v. 12, n. 1, p. 26-33, 2010.

MOREIRA T.R.; et al. Prevalência de tuberculose na população privada de liberdade: revisão sistemática e metanálise. Rev Panam Salud Publica. v. 43, n.16, Jan, 2019.

NIVEAU, G. Prevention of infectious disease transmission in correctional settings: a review. Public Health. v. 120, n. 1, p. 33-41, 2006. 
PAGANO, M.; GAUVREAU, K. Princípios de Bioestatística. São Paulo: Cengage Learning, 2010.

RAMOS, J, et al. Knowledge and perceptions of tuberculosis transmission and prevention among physicians and nurses in three Brazilian capitals with high incidence of tuberculosis. J. bras. Pneumol. São Paulo, v. 44, n. 2, p. 168-170, Apr. 2018.

RÊGO, A.S.; et al. Understanding and attitudes of relatives of inmates regarding tuberculosis: a descriptive study. Online braz j nurs. Niterói, v. 16, n.1, p. 17-27, mar 2017.

ROCHA, G.S.S., et al. Conhecimento dos agentes comunitários de saúde sobre a tuberculose, suas medidas de controle e tratamento diretamente observado. Cad. Saúde Pública, Rio de Janeiro, v. 31, n. 7, p. 1483-1496, July 2015.

SACRAMENTO, D.S, GONÇAVEZ, M.J.F. Situação da tuberculose em pessoas privadas de liberdade no período de 2007 a 2012. Rev enferm UFPE online. Recife, v.11, n. 1, p.140-51, jan., 2017.

SANCHEZ, A.R., et al. A tuberculose nas prisões do Rio de Janeiro, Brasil: uma urgência de saúde pública. Cad. Saúde Pública, Rio de Janeiro, v. 23, n. 3, p. 545-552, mar. 2007.

SANTANA, A.C.M., et al. Tuberculose no cárcere: percepção dos detentos sobre essa enfermidade. Rev enferm UFPE on line., Recife, v. 9, n. 6, p.8222-7, jun., 2015.

SIQUEIRA-BATISTA, R., et al. Conversações sobre a peste branca: formação em controle de tuberculose de profissionais da Estratégia de Saúde da Família no Estado do Rio de Janeiro. Cad. Saúde Coletiva (UFRJ), v. 19, p. 312-317, 2011.

SOUZA, K. M. J., et al. Atraso no diagnóstico da tuberculose em sistema prisional: a experiência do doente apenado. Texto contexto - Enferm., v. 21 n. 1, 2012.

STORLA, D. G.; YIMER, S.; BJUNE, G. A. A systematic review of delay in the diagnosis and treatment of tuberculosis. BMC Public Health. v. 8, n. 15. Jan, 2008.

VERONESI R, FOCACCIA R. Tuberculose. In: Melo, F.A.F. et al. Tratado de Infectologia. 4rd ed. São Paulo: Atheneu, 2009.

VITTI JUNIOR W. O controle da tuberculose nos presídios: atuação das equipes de saúde na região (DRS VI) de Bauru/SP. [Tese de Doutorado]. Botucatu: Universidade Estadual Paulista, 2013. 123fls.

WAISBORD, S. Participatory communication for tuberculosis control in prisons in Bolivia, Ecuador, and Paraguay. Rev. Panam. Salud Publica, v. 27, n. 3, p. 168-173, 2010.

WHO. World Health Organization. Global tuberculosis report, 2019. Geneva: World Hearlth Organization, 2019. Disponível em: https://www.who.int/tb/publications/global_report/en/. Acesso em: dez. 2019. 


\section{Authorship contributions}

\section{1 - Gilberto Caetano Brasil}

Universidade Fedral de Viçosa, Mestre em Ciências da Saúde https://orcid.org/0000-0002-5996-9129 - gilbertocbrasil@hotmail.com Contribuição: Conceptualization, Data curation, Investigation, Methodology, Writing - original draft

\section{2 - Rodrigo Siqueira Batista}

Universidade Federal de Viçosa e Faculdade Dinâmica do Vale do Piranda; PhD (Public Health), FIOCRUZ.

https://orcid.org/0000-0002-3661-1570 - rsbatista@ufv.br

Contribuição: Writing - review \& editing

\section{3 - Andréia Patrícia Gomes}

Universidade Federal de Viçosa; PhD (Public Health), FIOCRUZ. https://orcid.org/0000-0002-5046-6883 - andreiapgomes@gmail.com Contribuição: Writing - review \& editing

\section{4 - Renata Maria Colodette}

Universidade Federal de Viçosa, Mestrado em Ciências da Saúde https://orcid.org/0000-0002-2976-881X - renatacolodette@yahoo.com.br Contribuição: Writing - review \& editing

\section{5 - Deíse Moura de Oliveira}

Universidade Federal de Viçosa, Doutorado em Ciências

https://orcid.org/0000-0003-3804-7413 - dmouradeoliveira@gmail.com

Contribuição: Writing - review \& editing

\section{6 - Tiago Ricardo Moreira}

Universidade Federal de Viçosa, Doutorado em Saúde Pública https://orcid.org/0000-0002-6606-4942 - tiago.ricardo@ufv.br

Contribuição: Project administration, Supervision, Formal Analysis Writing - review \& editing 